\title{
The Urban Land Nexus- Challenges and Opportunities of Regularising Informal Settlements: The Case Studies of Dar es Salaam and Mwanza in Tanzania
}

Fredrick B. Magina 1, Alphonce G. Kyessi 2, and Wilbard J. Kombe 3

1 School of Spatial Planning and Social Sciences, Ardhi University, Tanzania

2-3 Institute of Human Settlements Studies, Ardhi University, Tanzania

To cite this article: Magina, F.B., Kyessi, A.G., \& Kombe, J.W. (2020). The Urban Land Nexus- Challenges and Opportunities of Regularising Informal Settlements: The Case Studies of Dar ed Salaam and Mwanza in Tanzania. Journal of African Real Estate Research, 5(1), pp.32-54. DOI: $10.15641 /$ jarer.v5i1.837.

\begin{abstract}
Informal settlements in Tanzania accommodate more than $70 \%$ of the urban population. Owing to this, the Tanzanian government has undertaken several initiatives to address the growing size and number of informal settlements. One such initiative is regularisation which addresses security of tenure for residents of these settlements. Most of the people living in informal settlements lack legal land ownership and as a result properties in such settlements have relatively less value and lack security of tenure. Providing security of tenure is believed to encourage investment into informal households and facilitate the provision of urban services. This study aims to evaluate the process of regularisation in three Tanzanian settlements; Magengenu in Dar es Salaam (Tanzania's largest city), Ibungilo and Isamilo in Mwanza city (the nation's second largest city). Using qualitative data the paper explores the challenges and opportunities that emerged from regularisation. Findings indicate that the regularisation process has facilitated the issuance of title deeds, increased land value and security of tenure. However, a number of challenges were highlighted during regularisation. These include an over-emphasis on the protection of private rights while undermining public interests, a lack of harmonised cost for regularisation, and prolonged delays in completing the regularisation process. These require policy actions, particularly reviewing the national informal settlements regularisation guidelines, as a way to address the weaknesses emerging from regularisation projects in the studied settlements. We conclude that land regularisation remains an important tool to enhance livable cities and protect long-term public and private interests in land development. In order to achieve this, supportive policy actions are required to support the protection of public interests in land regularisation and harmonise the costs of regularisation.
\end{abstract}

Keywords: Informal Settlements; Regularisation; Tenure Security; Public Interest; Tanzania 


\section{Introduction and Background}

Globally, more people live in urban areas than in rural areas. In 2014, 54\% of the world's population lived in urban areas and projections indicate that this will rise to $66 \%$ by 2050 (UN, 2014). Increased population growth and urbanisation are projected to add 2.5 billion people to the world's urban population by 2050 , with nearly $90 \%$ of this increase being concentrated in Asia and Africa (ibid). The ten cities that are projected to become megacities between 2016 and 2030 are all located in developing countries (UN, 2016).

The rapid growth of urban population has also led to the development of informal settlements in most of the world's cities. Apart from rapid population growth, other main causes of informality include issues relating to cultural, economic and environmental speculations and urban planning disciplines. From a social perspectives, people living in informal settlements have difficulties accessing basic social infrastructure services and facilities (Kyessi, 2002). Estimates have shown that $25 \%$ of the world's urban population live in informal settlements, with 213 million informal settlement residents added to the global population since 1990 (UN-Habitat, 2012). The World Bank report on Cities in Transition noted that in 2001, over 90\% of new urban developments in Africa would be informal. In addition, it was estimated that about 166 million people were living in informal settlements in Sub-Saharan Africa (World Bank, 2000).

In Tanzania, studies conducted in 1995 under the Urban and Housing Indicators Programme showed that at the national level, $70 \%$ of the population were living in informal settlements. Recent studies have revealed that the proportion of the urban population living in informal settlements has sharply risen to $80 \%$ and these areas are increasingly occupied by low and middle-income households (DCC, 2008; URT, 2013). Most poor people in urban areas resort to informal housing often located in marginal areas that are poorly served by public services or utilities. Further, poor people living in informal settlememts are vulnerable to natural disasters and other safety concerns such as fires and disease. Accessing housing that provides adequate shelter and physical safety is one of the greatest challenges confronting the urban poor (DCC, 2004). In an attempt to address informality and improve the quality of life in informal settlements, Tanzania has implemented several strategies over the past 60 years. These include squatter upgrading as well as site and services schemes of the 1960s and 1970s; community infrastructure upgrading of the 1980s up to early 2000s; and the programme to regularise informal settlements which commenced in the mid 2000s (UN-Habitat, 2010; Kyessi \& Sakijege, 2014).

De Soto (2000) defines land regularisation as the process, tools and procedures involving urban [land use] planning, cadastral surveying, and land titling and registration, i.e. upgrading and land legalisation of informal settlements (De Soto, 2000; Zakayo et al., 2018). Currently, regularisation is seen as the most effective option to formalise informal areas. It is, therefore, used as a tool to improve property rights (titling), provide infrastructure (proper streets, public lighting, etc.), facilities (police stations, schools, social 
services) and basic public services (water, energy, sewers) to the consolidated informal settlements (Guevara, 2014). The implementation of regularisation processes is usually supported through two main planning approaches; namely top-down or state-led approaches, and bottom-up or community-led approaches (Majani \& Magigi, 2006; Midheme, 2007; Duminy, 2011; Guevara, 2014). Midheme (2007) notes that the majority of regularisation projects are state-led where a top-down approach is adopted. This model pays little attention to the participation of beneficiaries such as community members. Community involvement in land regularisation, as widely discussed by Pretty and Frank (2000), has been perceived as a viable strategy to enhance the security of land tenure in informal neighbourhoods. It is an alternative approach to the state-led method to overcoming weaknesses relating to the lack of participation with the intended beneficiaries (De Soto, 2000). The approach is becoming widespread, particularly in the form of selfregularisation projects that are initiated by community organisations and interest groups within informal settlements. Although issues and challenges of state-led regularisation are largely known (Pretty \& Frank, 2000; Payne et al., 2009; Varley, 2016), grey areas still exist as to the opportunities and shortcomings of community-led regularisation projects.

The broad aim of this paper is to study the challenges and opportunities that emerge from state-led and community-led regularisation processes and how the two approaches have affected the economic and social well-being of landowners in affected communities. It uses two informal settlements in Mwanza city which were regularised by Mwanza City Council (MCC); representing a state-led regularisation approach, and one settlement in Dar es Salaam city which was regularised by a private planning firm and is more representative of a community-led regularisation approach. A qualitative design, by mainly employing interviews and focus group discussions, facilitated data capturing. The paper briefly provides literature on regularisation in developing countries before providing a brief discussion on the regularisation of informal settlements in Tanzania by highlighting the policy and legal provisions on the rights of land occupiers in informal settlements. Later on, the paper presents different programmes which have been implemented to solve issues in informal settlements before presenting the empirical results from which conclusions are drawn.

\section{Literature Review}

There exists a body of scholarly insights on regularisation programmes and how effective they have been in developing countries, particularly in Latin America and Africa. In Latin America, Kagawa and Turkstra (2002) applaud the Agency for Formalisation of Informal Property (COFOPRI) in Peru as the best example of a state-led approach in regularising informal settlements. They argued that the state recovered infrastructural investments by charging taxes, and property/construction interests capitalised on the valorised asset. In cases where the government is directly involved, the main financiers are also government agencies whose objectives are normally expressed in terms of 'so-many titles' within a given timeframe. Fernandes (2002) argues that the state-led approach seems to be largely propagated by the authorities' 
interest of taking into custody deteriorating physical conditions in such informal settlements. Objectively, they seek to bring the regularised areas under formal checks of development control, activate land markets and levy land rates. In Westen Africa, Payne et al. (2009) note that Senegal was the first country to implement a nationwide tenure regularisation programme based on the delivery of real property rights, transferred and mortgaged in urban areas. However, titles were granted for only a renewable period of 50 years; these could be converted into freehold titles once the land has been developed and the fees, taxes and costs of regularisation and the administration of the land are fully paid. Between 1987 and 2007, incremental improvements were carried out in four settlements in Dakar; tenure regularisation and physical upgrading activities were implemented (DurandLasserve \& Ndiaye, 2008). From the process, physical restructuring and upgrading, including the provision of basic services and roads were carried out. Importantly, the security of tenure was also improved. However, a significant percentage of people with the right to obtain titles had not yet received them. Until the conclusion of the projects, a negligible number of titles, amounting to less than 1,280 had actually been delivered (DurandLasserve \& Ndiaye, 2008). Despite significant measures taken in 1990s to simplify procedures and the setting up of a specialised entity responsible for speeding up the titling process, decades would be needed to be able to respond to titling needs.

In Cape Town, South Africa, Brown-Luthango et al. (2016) report the status of three informal settlements before and after re-blocking 1 (upgrading). Like any other informal settlements, such settlements had very poor living conditions, especially in terms of shelters and water drainage facilities. They also had a history of violence, shack fires, flooding and a significant lack of basic services such as electricity, water taps and toilets (ibid). After reblocking, infrastructure and services were provided; this made peoples' lives somewhat easier and gave them dignity. In this regard, a decrease in violence and crime was certain, residents had running water, electricity, flushing toilets; houses were made of walls and not in hokkies2 anymore (BrownLuthango et al., 2016). In Ekurhuleni metropolitan area in South Africa, regularisation was a response to the post-apartheid movement to redress years of dispossession of low-income black households. However, literature on the subject, [e.g. Payne et al. (2009)], shows that possessing a title deed has little effect on; (i) borrowing/accessing credit, (ii) owners' perception of their security of tenure, (iii) improvements and household investment, and (iv) quality of life. Banks do not cater for, or consider the value of, title deeds held by low-income households or low-cost properties and the 'titling system' does not help households to enter the property or land markets.

1 Reconfiguration and repositioning of shelters in very dense informal settlements according to a spatial framework drafted by the community with the aim is to use the spaces in informal settlements better in order to create space for provision of better services by local government.

2 Informal structures made of zinc and wood 
Land tenure regularisation in Rwanda, with the application of a wellfunctioning land information system, is one of the success stories of regularising informal settlements. A nationwide systematic land registration programme, with a goal to provide legally valid land documents to all rightful landholders, started in 2010 and was completed in 2013. A general/visible boundaries approach was used and data were collected in a highly participatory manner. For geospatial data, high-resolution orthophotos and satellite imagery was used. Teams comprised of locally recruited and specially trained staff outlined the parcel boundaries on the imagery printouts that were scanned, geo-referenced and digitised. By May 2013, about 10.4 million parcels were registered and 8.8 million printed land lease certificates had been issued. The achievements accrued include social harmony arising from reduced land conflicts and tenure security, increased investment in land, greater land productivity and an increased contribution of land as an economic resource towards national development (UN-Habitat, 2016). These types of approaches are becoming widespread, particularly in the form of selfregularisation projects that are initiated by community organisations and interest groups within informal settlements. In this context, it is conceived as a process of inclusion of different actors not limited to landholders or tenants in planning, facilitating, guiding and controlling land development activities.

In summary, De Soto (2000) argues that the ultimate advantage of regularisation is the increase in economic consolidation opportunities provided by legal land titles in terms of access to credit from financial lending institutions through the use of land titles as collateral. Furthermore, DurandLasserve \& Selod. (2007) observe that the social impacts of regularisation include increasing social status and integration or inclusiveness, health, education and fertility; and residential mobility and gentrification. DurandLasserve \& Selod (2007) and Brueckner et al. (2009) add that increased investment in housing or property; property values and costs of access; household incomes, employment and labour mobility; and tax revenue collection constitute the economic impacts of land titling through regularisation. Fernandes (2011) asserts that regularisation encompasses positive impacts related to building and the environment such as enhancement in the provision of and access to urban technical and social infrastructure services.

\section{Regularisation of Informal Settlements in Tanzania}

In Tanzania, the National Land Policy of 1995 clearly recognises the rights of land occupiers in informal settlements. The policy outlines that residents in unplanned areas ought to have their rights recorded and maintained by the relevant land allocating authority and that those records have to be registered (URT, 1995). On the other hand, section 4.1.4 of the National Human Settlements Development Policy, NHSDP (2000) recognises informal settlements in urban areas and acknowledges that they are a result of rapid population increase that is associated with high natural birth rates and sustained rural-urban migration. An inadequate supply of planned land compounds this problem. Most importantly, both policies recognise the emergence and development of informal settlements and the need to 
regularise them (URT, 2000). In particular, the Land Policy prohibits demolition of unplanned settlements and advocates upgrading and provision of basic community facilities, except settlements on hazardous areas. Likewise, the NHSDP, in recognition of the emergence of informal and unserviced settlements, provides for upgrading and regularisation of such settlements by their inhabitants through Community-Based Organisations (CBOs) and Non-Governmental Organisations (NGOs) with the government playing a facilitating role (URT, 2000).

Similarly, the principal legislation such as the Land Act No. 4 of 1999 Section 57 spells out the criteria for declaring a scheme (URT, 1999). These include, (i) habitation of dwellings of their own construction, (ii) lack of apparent lawful titles, (iii) existence of customary land law in the area, (iv) substantial development of the area, (v) Likelihood of the area to be declared a planning area, (vi) substantial number of well established and settled people in the area in a substantial period of time, and (vii) substantial self-housing and business investments in the area. Section 60 of the Act lists the contents of regularisation schemes to include:

- A survey, adjudication and recording of the interests in land claimed by those persons occupying land in the regularisation area;

- A readjustment of the boundaries of plots of land;

- A framework for the better planning and layout of the land including the pooling, sharing and redistribution of rights in land;

- Involvement of the local authorities having jurisdiction in the regularisation area in the implementation of the scheme;

- Involvement of the people whose land is the subject of the scheme of regularisation in the implementation of the scheme;

- Assessment and payment of any compensation that may be payable in connection with the implementation of the scheme; and

- A budget for the scheme.

Furthermore, section 23 of the Urban Planning Act No.8 (2007) recognises informal settlements as planning areas and endeavours to regularise and prepare regularisation schemes of these settlements. Furthermore, the document outlining the guidelines and procedures for implementation of schemes of regularisation in Tanzania (2008) highlights the process of the preparation of regularisation schemes, contents and outputs. Commenting on regularisation undertakings and its associated challenges in Tanzania, Zakayo et al. (2018) argue that regularisation projects should be viewed as owned by the local communities and coordinated by government. However, the central role of local or neighborhood leaders in regularisation has been ignored and not considered important. As such, after the completion of the land regularisation leaders do not mobilise local communities to construct roads set aside for public use, apply for title deeds, find permits for home improvements or proper waste disposal sites. Thus, the desired community development objectives of land regularisation are not truly realised.

As highlighted earlier, different programmes have been implemented to address the issue of informal settlement formation and development in 
Tanzania. These include slum clearance (from 1960s to 1970s) which aimed to upgrade informal settlements and improve urban environments so as to rid Dar es Salaam's 'eyesores' of squatter settlements by improving housing for the poor. The government implemented its slum clearance and redevelopment policy by developing high-quality formal buildings on cleared sites (Kyessi, 1997; URT, 2000; World Bank, 2002). This approach removed residents of informal settlements and placed them on the urban periphery with limited access to employment and public services. Following the failures of the slum clearance programmes of the 1960s and 1970s, the squatter upgrading programme was implemented in the late 1970s and early 1980s, largely aimed at improving network infrastructure. Overall, the approach was closest to a multi-sectoral typology, which was largely subsidised by the state. The projects actively involved the communities and gave responsibility for scheme management and subsequent operation and maintenance to the beneficiary community (World Bank, 2002). The implementation of these projects considered community members in planning, designing and construction of infrastructure facilities and community labour was used during construction. The involvement of communities in decision-making and helping to provide what is required in their respective communities, and the provision of affordable solutions seemed to be accepted. One major aspect to note is the fact that the government recognised the need to improve shelter, basic services in slums and squatter settlements and the importance of security of tenure as opposed to evictions (World Bank, 2002).

Sites and Services Projects, whose implementation started from 1972, was famous from the 1970s-1990s. Primarily, the programme aimed to provide basic infrastructure and services together with community facilities in new informal areas. The programme also focused on the resettlement of households which resided in hazardous and flood prone areas, particularly in river valleys. A World Bank study in the Sites and Services areas of Dar es Salaam found that five years after the project completion date, only $48.3 \%$ of the plots that were developed had occupants in them, $22 \%$ had not reached occupiable conditions and $26.6 \%$ had not been developed. At the end of the extensive programme around 3,000 plots (which were allocated between 1979 and 1983) were totally undeveloped in 1988 (URT, 1992). Due to these dissatisfying results, this project was discontinued in the early 1990s.

From the early 2000s onwards, regularisation of informal settlements gained prominence primarily because it incorporated tenure improvements to residents. The approach also came into effect following the enactment of the Land Acts No. 4 and 5 of 1999. The Acts provide for the adoption of regularisation of informal settlements with the emphasis of titling properties and plots. With the exception of Dar es Salaam and Mwanza, which received financial assistance from the central government and donor funding, the other five urban local authorities of Dodoma, Moshi, Tanga, Iringa and Morogoro implemented similar programmes using their own budgets (Kyessi \& Sakijege, 2014). In the beginning, all these approaches were implemented by the Ministry of Lands or local authorities within which informal settlements were located. The biggest challenge faced by the programme was the failure in meeting the objectives of the projects in terms of regularising land in all of 
Dar es Salaam's unplanned areas. Further, the sustainability of these projects was severely hampered if donors withdrew, or when the country's priority in the fiscal year was not on land. Additionally, during the implementation of regularisation projects, communities received little involvement and the completion of such projects was achieved at the lowest standards. There is growing evidence that suggests that community-led regularisation projects are likely to be more sustainable and successful at driving socio-economic upliftment in informal settlements.

\section{Conceptual Base}

Literature provides ideas on regularisation by emphasing the economic dimension and implications of urban illegality. De Soto's approach has stressed the significant impact that comprehensive regularisation programs could have on the broader urban economy by linking the growing informal extra-legal economy into the formal economy (De Soto, 2000; Bourbeau 2001). Moreover, De Soto argues that such public policies can be instrumental in reducing social poverty. In De Soto's view, small informal businesses and precarious shanty homes are essentially economic assets; 'dead capital' that should be revived by the official legal system and turned into liquid capital so people could gain access to formal credit, invest in their homes and businesses, and thus reinvigorate the economy as a whole (De Soto, 2000; Fernandes, 2002). Fernandes (2002) argues that de Soto has failed to consider the essential gender and environmental implications of land legalisation. He proposes the preparation of new tenure policies to integrate four main factors: legal instruments that create effective rights; socially oriented urban planning laws; political-institutional agencies and mechanisms for democratic urban management; and inclusionary macrosocioeconomic policies. The search for innovative legal-political solutions also includes the incorporation of a long-neglected gender dimension and a clear attempt to minimise the impacts that such policies have on the land market.

In line with the theoretical perspectives of De Soto (2000), Kyessi and Tumpale (2014) argue that regularisation is supposed to provide a number of benefits that property owners do not have access to when operating in the informal sector. First, it makes people accountable through integration of all property systems under one formal property law (De Soto, 2000). Secondly, regularisation makes assets fungible by transforming assets from being in a less accessible condition to one that is more accessible. Thirdly, it protects transactions since all property records (titles, securities and contracts that describe the economically significant aspects of assets) are protected. Additionally, regularisation safeguards the interest of governments since the government receives economic benefits including a broader tax base and information to inform policy decision making. The expanded tax base that accompanies regularisation can be used to provide much needed public goods and services, including: education, health care, and systems of social insurance and welfare (Kyessi \& Tumpale, 2014). 
Emanating from the foregoing literature, the conceptual underpinnings of this study hinges on the sustainability concept whereby the three dimensions for regularisation processes emerge. These include cost-effectiveness (economic production and viability) as Jones (2017) provides, replicability, and access to and use of public spaces through a multi-level stakeholder approach (Hurni, 1997). In this case, regularisation projects are expected, among other things, to embrace land uses with long-lasting utlilisation, safeguard public interests, and share project costs in order to alleviate poverty and minimise the effects of informality in unplanned settlements. Zakayo et al. (2018) provide that land regularisation and community development are interlinked in such a way that land regularisation aims to ensure access to social services such as roads, waste disposal points, health and education facilities, open spaces and the right of occupancy. When such projects are successful during their pilot phases, they ought to be scaled-up to other informal settlements, and planning and implementation strategies should also be transferrable. This study takes onboard capacity building of local communities as one of the key conceptual attributes that underlines the essence of regularisation. On this aspect, Magigi (2013) argues that if communities are aware of the process and outputs of regularisation they can ensure that urban land is properly managed and efficiently utilised for increased productivity and sustainable use. Moreover, designation of land for vital public uses, including access to areas designated for various land uses, including social services, is necessary. This is due to the fact that public and outdoor spaces are critical for supporting social and economic activities in regularised settlements which usually diminish as a result of the densification process (Sliuzas, 2004). Based on the above, the study intends to investigate the challenges, potentials and the importance of community-led land regularisation in Tanzanian informal settlements.

\section{Methods and Data}

The study applied a multiple case study approach whereby qualitative methods were used to collect data from three selected informal settlements; Ibungilo and Isamilo in Mwanza city, and Magengeni in Dar es Salaam city. The selection of these settlements is based on the fact that regularisation has taken place and land occupiers have started experiencing some physical and structural changes to their properties. Further, the case studies selected represent both the state-led/top-down approach to regularisation as well as more community-oriented approaches to regularisation. Before the commencement of fieldwork, an extensive literature review was carried out in order to underscore national procedures for undertaking regularisation exercises and what is expected from them. During fieldwork, discussions were held with key informants who included Ward Executive Officers (WEOs); Mtaa Executive Officers or chairpersons; and Mwanza City Council officials who carried out regularisation in the selected settlements in Mwanza. In addition, staff members of the Applied Geodesy Consultancy Company which carried out the more community-led regularisation in Dar es Salaam were involved. Members of the Regularisation Committees in each settlement were also interviewed. Thereafter, interviews were conducted with 180 land occupiers (households), 60 households from each settlement, who were 
purposefully selected with the intention of learning from real life experiences of the regularisation exercises which took place. Interviews were grouped into relevant themes emanating from research questions to form a detailed set of findings. The main themes related to the motives of regularisation, how regularisation projects were acquired under a community-led regularisation approach, and the emerging challenges and opportunities of regularisation projects. The results were presented in the form of texts, tables and figures. The empirical evidence was equally triangulated with the existing literature on the links between regularisation and social, economic and spatial aspects. This allowed the findings and the subsequent conclusions to be articulated within the existing body of knowledge on regularisation.

\section{Findings and Discussion}

\subsection{The Need for Regularisation}

Generally, the push to undertake regularisation projects in the study settlements was driven by the unaffordable charges which individuals who want to survey and title their plots would pay if they execute the project individually. The majority of land occupiers in the informal settlements, most of whom are low-income earners, could not afford the cost. Therefore, the implementation of the regularisation programme was an opportunity to pool their limited individual resources and bargain for a lower regularization cost. Asserting the foregoing, the Chairperson of Magengeni Mtaa noted:

"Generally, apart from huge sums charged, individual-led regularisation have had limited success. Each one struggled on his/her own; someone could spend as much as TZS 4 million; 5 million or even 6 million [equivalent to US\$1,739 - \$2,609], the majority could not afford this".

(Chairperson, Magengeni Mtaa, 2018)

Unlike Isamilo and Ibungilo settlements in Mwanza City whereby residents showed an interest in regularisation back in 2015, the decision to regularise Magengeni settlement in Dar es Salaam was largely driven by the central government. The Minister for Lands, Housing and Human Settlements Development declared that all informal settlements in Dar es Salaam and other urban centres in the country will be regularised. The government's decision to regularise all informal settlements in all urban areas was made as he spoke in the Tanzania's Land Surveyors' Conference and first Annual General Meeting in 2016. Speaking at the Ministry of Lands, Housing and Human Settlements Development (MLLHSD) the Minister noted:

"...85\% of all land in the country is not surveyed and the majority of people continue living in unplanned settlements. The government is losing revenue because the largest part of land being unsurveyed..."

(Minister for Lands, 2016)

A quarter of interviewed residents (45 out of 180) in three settlements noted that they wish to regularise their settlement in order to get title deeds which could enhance tenure security and enable them to use their property as collateral to access funds to improve their economic and social well-being. 
"We bought land at a cost and others inherited from their fathers but we cannot use it besides own occupation and renting out some spaces. In planned areas where people have title deeds, they have turned their papers into cash through mortgaging and they have intensified business and other activities. They are economically stronger than we are. We also expect to improve our economic condition when we get the deeds".

(Interview with community members, 2018/2019)

From the Minister's speech it is noted that, on the one hand, residents understand the outcome of tenure security resulting from the issuance of certificates of occupancy. On the other hand, they express their concerns and reservations on the obligation to pay tax and even an increase of tax over time, following the formal recognition and registration of their properties.

\subsection{Acquisition of Projects Under a Community-led Regularisation Approach}

In all the three settlements the bottom-up regularisation approach involved a number of actors from the local community level to the government level. In Magengeni settlement a private consultancy firm, the Applied Geodesy Consultancy, directly contacted the community and held discussions with Mtaa leaders on the need for regularisation and how to carry it out in the settlement. Thereafter, the firm approached the ward level leaders (WEO and Ward Councilor) and finally the Temeke Municipal Council to get approval and permission to undertake the exercise in the settlement. After getting the permission by the Municipal Director, the firm submitted a copy of the permit to the Ward Development Committee (WDC) and to the Mtaa leaders. The permit autonomised the firm to carry out regularisation which included conducting public meetings, entering into agreements on cost, establishing Mtaa Regularisation Committees, selecting committee members, opening bank accounts, and execution of the project. The approach in Dar es Salaam slightly differs from the one adopted in Mwanza city in 2015 whereby communities in Ibungilo and Isamilo Mtaas led to initiation to the City Council requesting the Council to regularise their settlement. The City Council approved the request and advised communities to wait for the finalisation of the Mwanza City Master Plan, which was being finalised by 2015. This stagnated the initiation and implementation of regularisation projects in areas which were determined to be regularised. As a result, land occupiers perceived it as a laxity of the City Council to effectively manage and implement community projects.

Concerning the initiation of regularisation projects in the three study areas, we observe two main drawbacks. First, although both are termed communityled regularisation projects, there is a difference particularly regarding project initiation in the Magengeni area. In this area, the consent to undertake the project was granted on the understanding that it is was a community-led project. Secondly, the procedures that the private planning firm used to execute the project differed from the official protocols issued by Municipalities. For instance, normally private consulting firms are required to consult with respective Municipalities so as to get their endorsement on areas that have to be regularised. After the consultation, the firm has to get 
approval from the residents in the area, including land occupiers. Through public meetings, information is circulated to all residents and once this is done the firm notifies the Municipality about the resolution of the community. Finally, the firm submits the documents to the Mtaa leaders and a copy to the WDC for records. Commenting on the failure of private consultants not complying to the procedures of regularisation process, residents admitted the disappearance of such firms after being paid part of their regularisation charges. This trend has forced the government both at central and local levels to closely follow-up and monitor regularisation projects implemented by private consultancies. In this case, local governments require consultants to submit progress reports and outputs as per contracts which are later sent to the ministry for records.

\subsection{Challenges of Regularisation}

\subsubsection{Property Demarcation and Accessibility in Hilly and Densely Built} Areas

The hilly and rocky nature of Mwanza city, and particularly the Ibungilo and Isamilo settlements, coupled with the small plot sizes in all three settlements was the main challenge during the cadastral survey to demarcate plot boundaries. This is due to significant housing densities and the lack of land for public use. Whatever is left unbuilt comprises of rocky areas which cannot be used for active recreation or similar uses (see Figure 1). Some of the beacons were installed on rocks while others were mounted on existing facilities such as septic tanks or soak away pits. Also, due to excessive densities and the hilly nature of the settlements' terrain, the access roads reserved do not provide convenient circulation of people, many run against the contour alignment leading to sharp gradients.

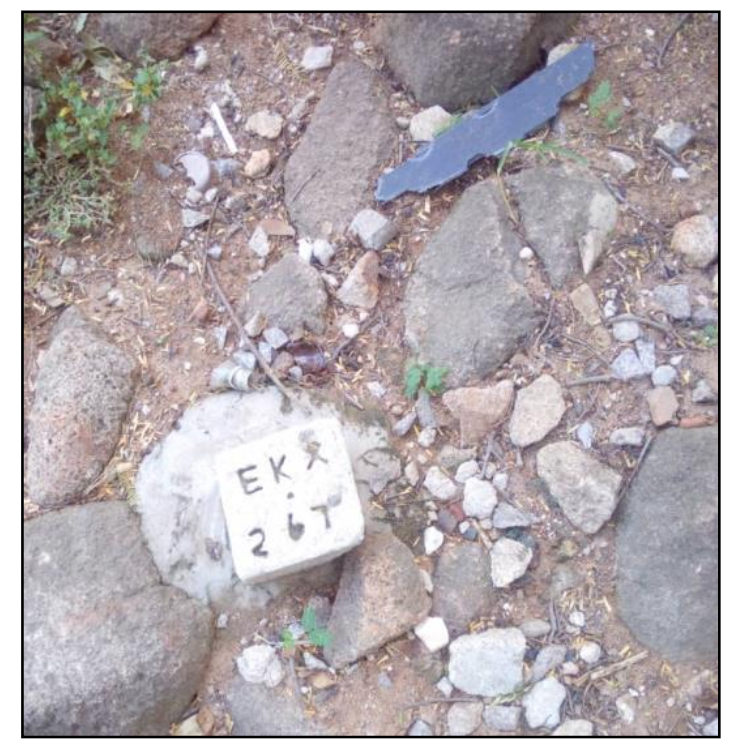

Figure 1: Land Demarcation at Isamilo and Ibungilo Informal Settlements

Source: Fieldwork at Ibungilo and Isamilo, 2019

\subsubsection{Private Land Rights, Land for Public Uses and Land Use Planning}


In Ibungilo and Isamilo settlements, land for public uses, including areas for social services such as a local market and nursery schools were set aside by residents. This was established through collective engagement and negotiations augmented by a strong role played by local (Mtaa) leaders collaborative planning (Kyessi, 2007). Additionally, land was reserved for technical infrastructure services, including road networks and the provision of simplified sewerage systems (which have been provided in some of the housing areas such as in Kigogo, Mirongo and some parts of Mabatini). In this regard, some structures which fell on the land set aside for public uses have been earmarked for demolition (see Figure 2). Some residents have taken initiatives to improve their toilets ready for the upcoming simplified sewerage project that was expected to be implemented from mid 2019 (Figure $3)$.

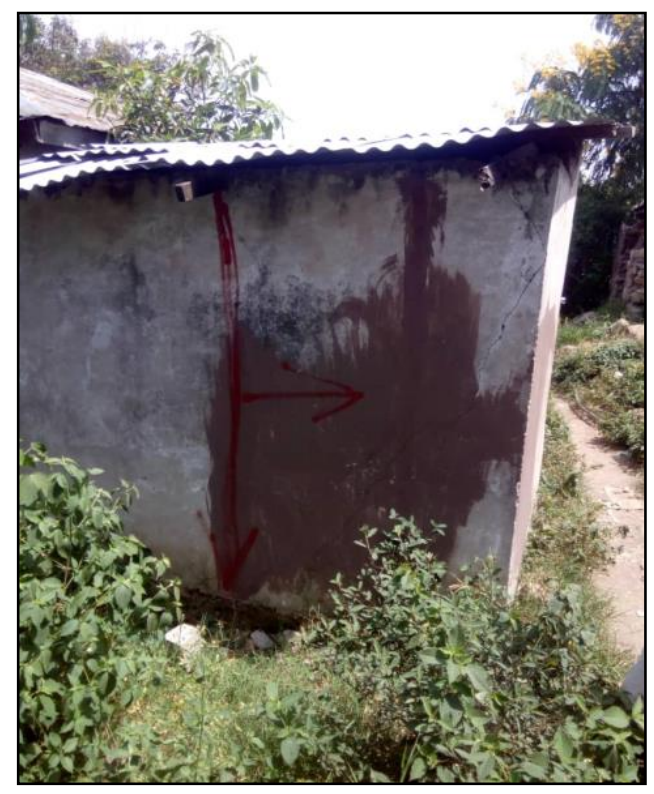

Figure 2. Land reserved for a $4 \mathrm{~m}$ road with Part of Building to be Demolished

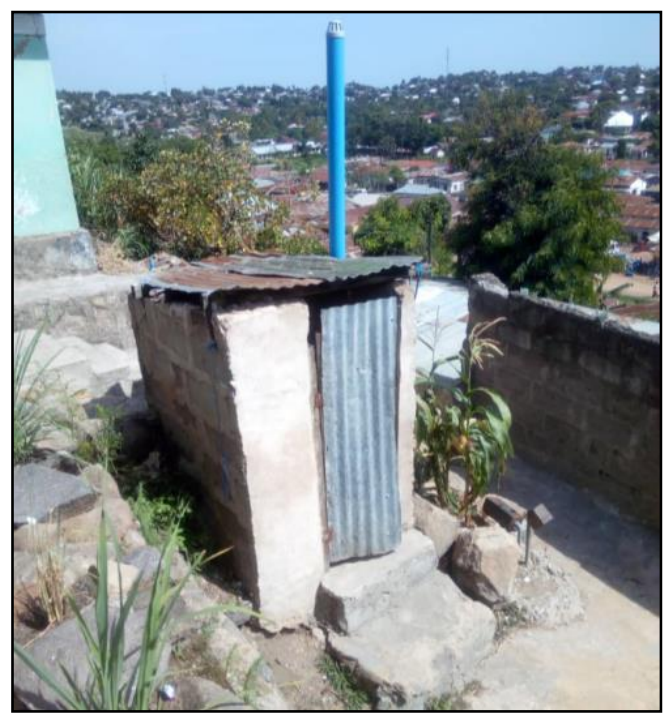

Figure 3. Toilet to be connected to a sewer 
Source: Fieldwork at Ibungilo and Isamilo, 2019

As noted earlier, in the two settlements of Ibungilo and Isamilo, which have quite small plots of $20 \mathrm{~m}$ x $20 \mathrm{~m}$ or less, Mtaa leaders have displayed an unquestionable ability and power to convince land occupiers to contribute land required for public uses. In contrast, residents at Magengeni settlement and many densely built informal settlements in Dar es Salaam focus on private uses and disregard or downplay public rights and needs during regularisation. In this regard, many are not willing to offer part of their land for public use. Where attempts are made to negotiate with landowners they often demand too much compensation. In other cases, agreements may be reached for land occupiers to contribute part of their land for public use, but during implementation problems and disputes arise, again leading to protracted litigations. This is particularly prevalent on land for road networks because neighbouring land occupiers are obliged to surrender some of their land at will for such public use without compensation. As such, the public continues to labour under the same problems that existed before the regularisation processes, even after the completion of such projects. These failures are partly contributed by the local institutions, especially the Mtaa Regularisation Committees and leaders, which do not control and regulate the provisions and proposals made in the regularisation plans and reports. Therefore, it is not only important to identify areas for public use but most important is to earmark such areas.

In cases where residents fail to provide land for public use contrary to the provisions of the Land Regulations for 2001, planning authorities are obliged to liaise with communities and landowners to surrender part of their land for future provision of infrastructure and other community facilities, such as school plots, markets, roads, areas for water tanks and any other public land. In practice, institutions responsible for carrying out regularisation exercises usually identify property owners with their individual properties, but they do not negotiate land for other public uses. These include areas for open spaces, accessibility, health care and education facilities, to mention a few. In negotiating public spaces within informal settlements, planning entities (public or private) facilitate communities by emphasising the importance of access to such spaces (e.g. waste deposits points, health and education facilities) in community development. However, a critical role is played by local leaders and members of the planning committee in their areas of jurisdiction. In this regard, landowners are convinced to share part of their land. In cases where landowners agree to give away part of their land, regularised neighbourhoods become vibrant, and accessible to all community members.

\subsubsection{The Non-harmonised Cost of Regularisation}

Costs that land occupiers are required to pay consultants varied despite the fact that various informal settlers do not have the same income or social status. In Isamilo and Ibungilo settlements, which are located next to each other, the amount which was charged was TZS 150,000 and 200,000 (nearly US \$65 and US \$87) per plot respectively. In Magengeni the cost was TZS 250,000 (about US \$109). The regularisation guidelines allow communities 
and consultants to agree on the charges after considering the socio-economic characteristics of residents. Despite this provision, landowners in Ibungilo settlement were not satisfied because they paid more than their Isamilo counterparts. Their complaints appear genuine since initially the cost per each land parcel in Isamilo settlement was agreed to be TZS 200,000; but the residents made a special request to Mwanza City Council (MCC) to reduce the charge and it was granted. Upon the acceptance of the cost reduction, their counterparts in Ibungilo settlement also requested the City Council reduce the cost from TZS 150,000 to 200,000, but the MCC declined to reduce by arguing that a consensus had already been reached. Residents lamented on the double standard and they associated the behaviour with corruption by urban professionals. Moreover, the government of Tanzania has been proactive about monitoring the cost charged in the regularisation programmes. In July 2018, the Minister for Lands mentioned while officiating the draft of the Dar es Salaam Master Plan (2018-2038) to stakeholders, and declared TZS 250,000 as the indicative cost for regularising a plot. Before the Minister's declaration, private firms were charging between TZS 500,000 to TZS 800,000 (equivalent to US \$217 and US \$348) per plot. The quote below elaborates:

“...regularisation exercises shall be supervised by District Land Officers instead of Ward Councilors and Sub-ward leaders. Each landowner shall contribute TZS 250,000 per plot and not TZS 500,000 or 800,000... After an investigation I have realised that that the actual cost does not exceed TZS 250,000 to plan and survey a single plot. Private companies should compete through a formal tendering procedure at district levels..."

(Minister for Lands, 2018)

Eight months later (April 2019), the Minister made another announcement on the indicative cost when he met private planning and surveying firms carrying out regularisation activities. He lowered the earlier figure to only TZS 150,000 per plot. As reported by a newspaper article below, according to the Minister, this decision emanated from the slow pace of regularisation exercises. Only a few landowners in urban areas have regularised their properties since the commencement of the exercise. He added that most landowners could not afford to pay TZS 250,000.

“...from now, the cost for regularising one plot will not exceed TZS 150,000 per plot. Firms which shall not comply with this will be punished including being deregistered... the regularisation exercise has been very slow and we have discovered that only $30 \%$ of informal settlements in urban areas has been regularised since the exercise started. This has been attributed to low incomes of the majority of people who cannot afford the cost..."

(Global Publishers, 2019)

Residents have repeatedly complained about the high costs charged for regularisation. For instance, during interviews in Magengeni settlement in March 2019, about 58\% of the interviewees proposed that the cost of regularisation should be lowered, while about $3 \%$ proposed that it should be waived completely. The rest (31\%) had no problems with the current cost. It is important to note that these are also costs related to supervision of the regularisation exercise by the Mtaa Regularisation Committee which usually 
gets $5 \%$ of the regularisation cost per plot. In addition, individual landowners are required to pay charges related to title deed processing and issuance.

In this study we argue that the costs charged in Isamilo and Ibungilo settlements were higher than in Magengeni settlement due to the fact that the consultant involved in the Magengeni settlement was a public entity; the MCC, who used public equipment at no fee and professionals who are paid salaries by the state. Besides, the public consultant is not subjected to income tax or other fees. On the other hand, the private firms are required to pay income tax to the Tanzania Revenue Authority (TRA), some amount to the professional bodies, annual fees to the Business Registration and Licensing Authority (BRELA) and the local authority. In reality, regularisation projects are practically expensive in terms of what landowners contribute as opposed to the idea of assisting poor people owning properties in informal settlements. For instance, landowners at Tandala (Makete) in Tanzania had to pay only TZS 200,000 (US \$87) for a residential plot, TZS 250,000 (US \$109) for a residential cum commercial plot and TZS 300,000 (US \$131) for a commercial plot. At Tuelewane (Morogoro) and Indundilanga (Njombe), property owners were required to pay TZS 120,000 (US \$52) and TZS 350,000 (US \$152) respectively for planning and surveying in addition to statutory fees and charges for titles (Kusiluka \& Chiwambo, 2018). A recent regularisation project undertaken in Makongo Juu in Dar es Salaam shows that a landowner of a plot measuring $1,000 \mathrm{~m} 2$ was required to pay a premium of TZS 875,000 (around US \$380) to have a land title while owners of a similar plot size in Kimara had to pay TZS 375,000 (US \$163) per plot (Kironde, 2019).

\subsubsection{Prolonged Delays in Completing Regularisation Processes}

Regularisation projects in the two settlements in Mwanza began in early 2018 and mid 2018 in the Magenegeni settlement. At the time of this study in March 2019, more than a year later, the projects were yet to be completed. In some Mtaas, especially in Ibungilo, land parcels with disputes had not been served and thus the project had not been completed. The time which these regularisation projects has taken is not in line with what is provided for in the regularisation guidelines or contracts between the community and the consultant; which was stated to be six months. In addition, delays in the approval of the survey plans resulted in the late issuance of title deeds for the regularised areas. Although the process of land regularisation and formalisation in Isamilo was completed in April 2019, households are not yet informed when they will get their land titles. Furthermore, residents and Mtaa leaders expressed concerns on the delays noting a lack of activity of the MCC and Applied Geodesy Consultancy Company after collecting money from residents in accordance with the agreements made. As a result, some of respondents interpreted regularisation as a strategy to generate revenues of the city council and for individual benefits. 


\subsection{Opportunities Arising from Regularisation}

\subsubsection{Increased Land Value}

Generally, land value has increased in the settlements soon after carrying out regularisation. Before regularisation, land prices in Isamilo and Ibungilo were relatively low. For instance, for a small plot measuring $5 \mathrm{~m} \times 5 \mathrm{~m}$ the selling price was between TZS 30,000 and TZS 35,000 (US \$13.20 and \$13.35) in 2000 and 2004 respectively. For medium sized plots measuring $35 \mathrm{~m}$ x $35 \mathrm{~m}$ the selling price was about TZS 100,000 to TZS 150,000 (US $\$ 43.86$ to $\$ 65.80$ ) for the years 2000 and 2004 respectively. By the year 2009 it had shot up to TZS 500,000 (US \$219.30). At present, after regularisation, the price of medium size plots measuring $25 \mathrm{~m} \times 30 \mathrm{~m}$ had increased to TZS 4-7 million (US $\$ 1,754$ - $\$ 3,070$ ) depending on the size and location of a plot; some are now being sold up to TZS 30,000,000 (US \$13,158). In addition, rent in the area has also gone up. For instance, respondents claimed that between 2010 and 2015, i.e. before regularisation, a room was rented for TZS 10,000 (US $\$ 4.40$ ) per month. Currently, the same room size is rented at between TZS 15,000 and TZS 30,000 (nearly US $\$ 6.60$ and \$13.20) per month. These rental charges exclude water and electricity bills. Regularisation is among the factors that have influenced changes in land and housing value even though the regularisation processes were still ongoing in the settlements. In this regard, $30 \%$ of the 40 households interviewed in Isamilo and Ibungilo mentioned that regularisation has contributed to the increase in land value. Also, locational advantages i.e. raised hills, proximity to the Central Business District (CBD), public services such as MCC offices, Kirumba Mwaloni and Nyamanoro markets, Sekou Toure and Makongoro hospitals, good scenery of Lake Victoria and proximity to other areas within the city were ranked high and considered important drivers for increased land value. These findings suggest that the real estate market (land and housing) is thriving in regularised settlements because of the services that are in the provision pipeline. To real estate managers, the increase in land and housing prices and rents may also imply speculation in order to be supplied when market prices become more stable.

\subsubsection{Increased Tenure Security}

Land regularisation has increased security of tenure and confidence of residents to own and invest in land. Though not all people in the regularised settlements have received their land titles yet, they still feel more secure on, and confident with their land than before regularisation of the settlements. Interviews with households who own land in the settlements revealed high expectations on land. Some are expected to make improvements to their building structures and build new houses, while others believe that land values will further increase. Furthermore, new and permanent business enterprises are increasingly coming into the settlements and many believe that once they get titles they will identify themselves as rightful landowners and no more evictions will be effected, as stressed by the quotation below:

"...I have confidence in further developing my land after the regularisation. Before it we were uncertain whether we would continue living in this area. 
We were told and some notices of eviction were on the way. Now it is no longer the case..." (Interview with community members, 2019)

Regarding the quotation, land occupiers and developers stated the economic externalities resulting from investments on their land. These include getting a sustainable and regular income through renting out commericial spaces and also running their own businesses. Profit from these premises can eventually help land occupiers fulfil different family and development obligations such as paying for their children's schooling needs, attending to domestic expenses, accessing healthcare services and advancing in real estate investments for more income generating opportunities. Before regularisation, people were hesitant to invest on land due to threats of eviction. Additionally, conversations around land security (after regularisation) were aired out by Mtaa leaders. For instance, during interviews with the Chairperson of Isamilo North Mtaa he noted that now people are happier than before regularization:

"...It was very difficult to visit and talk to them on land matters before regularisation because in the past the government wanted to evict people from these areas. Some started thinking of selling their land and some built just inferior houses. After regularisation, things have turned upside down and no one is willing to sell his/her land... If you would come a few months before regularisation, you could not get people to respond to your interviews...The Mwanza City Council has really heard our voices and made a positive response".

(Isamilo North Mtaa, 2019)

The majority of the residents from Ibungilo and Isamilo knew the importance of land titles and perceived the regularisation exercise as a vehicle to purely enhance tenure security, and did not recognise its value as a vehicle for economic advancement and prosperity.

\subsubsection{Provision of Land for Technical and Social Services}

As discussed earlier and also presented on Figure 3, residents in Ibungilo and Isamilo settlements willingly provided their land for the simplified sewerage system project. The provision of land for public use including land for public utilities following regularisation has, in turn, attracted Mwanza Urban Water and Sanitation Authority (MWAUWASA), the European Investment Bank (EIB) and French Agency for Development (AFD) to provide support to extend the project in the two settlements which already operates in Kigogo, Mirongo and parts of Mabatini wards in Mwanza city. Moreover, local markets and nursery schools will be provided in the settlements as land for such uses has already been reserved through the regularisation process.

\subsubsection{Resources Mobilisation from Stakeholders}

In regularisation projects in Dar es Salaam and Mwanza cities, varying resources were necessary for a successful implementation. In Magengeni settlement, the surveying firm, namely the Applied Geodesy Consultancy, collaborated with the Mtaa leadership to initiate the process. In addition, the firm secured the permission from the planning authority and the Temeke Municipal Council to carry out the regularisation exercise in the settlement. Moreover, the firm mobilised and conducted public meetings to introduce the 
project to residents, and to identify land rights in preparation of the layout plan of the settlement. In Ibungilo and Isamilo settlements these activities, except the acquisition of a permit, were carried out by the planning authority; the MCC. Financial resources in the two cities were solicited from the community under the facilitation of Mtaa leaders and the respective Regularisation Committees. Owing to limited resource capacities of the public sector, community self-financing regularisation projects have increasingly been popular. The pooling together of resources of communities has facilitated the implementation of regularisation projects both in Dar es Salaam and Mwanza cities. While human resources fast-tracked the technical procedures, material and social needs; financial resources facilitated financing of the projects. It is important to note the investment that community stakeholders extended towards the regularisation exercise, which demonstrates aspects of the sustainability of community-led approaches to informal settlement regularisation.

\subsubsection{Increased Government Revenue}

Regularisation projects enable governments to collect more revenues in the form of land tax. This is largely seen as beneficial as it enables government to reinvest collected taxes into the regularised communities (where they would not have received revenue from before). This provides opportunities to improve urban services in these communities and further support the upliftment of these areas. However, many are skeptical about the government's intentions behind the regularisation programmes and believe that they are driven primarily to increase revenue. Improving security of tenure by issuing titles to individual land occupiers in informal settlements appears to be a secondary issue. Therefore, the emphasis does not seem to be on land use, planning and regularisation standards (WAT-Human Settlements Trust, 2010; Kironde, 2019). Kironde (2019) argues that the current Ministry of Land's interest seems to be collecting land tax to boost government revenue from land, particularly in cities and other urban centers. This is supported by the speech made by the Ministry of Lands outlined earlier in the findings section. Further, a study carried out in 2019 on formalisation of properties in informal settlements, land rent ranged from TZS 1,200 to 12,000 (US $\$ 0.53$ to $\$ 5.30$ ) per year, while property tax in a surveyed plot was expected to increase from TZS 10,000 to TZS 30,000 (US $\$ 4.40$ to $\$ 13.16$ ) per year (WAT-Human Settlements Trust, 2010). While these amounts may seem nominal, they are a serious challenge to landowners in regularised settlements. In this regard, most landowners are unable to meet the land tax requirements of government as it is even difficult for them to cover their basic costs of living.

\subsubsection{Creating Awareness for Regularisation}

The projects studied created significant awareness on regularisation processes and what is expected from them. This awareness was created through public meetings in study settlements. In particular, the meetings were intended to help people understand and internalise the importance of land holders having certificates of rights of occupancy. In these meetings, Mtaa leaders, especially the chairperson and consultants, play a vital role in mobilising land holders 
to commit themselves to the regularisation exercise. As a result of public meetings and the resultant awareness, there was a better understanding of regularisation and its importance. This in turn helped soften land holders to donate part of their land for public uses. Further, this helps to build a familiarity and acceptance of regularisation in other informal settlements.

\section{Conclusion}

The evidence from regularised settlements in Dar es Salaam and Mwanza cities have shown that land regularisation can be an important tool for controlling urban areas which have developed outside the planning framework. Moreover, regularisation is an indispensable tool for increasing land value and ensuring tenure security of people who live in informal settlements. One of the privileges which households have gained from the regularisation project is the increased recognition of their rights to occupy and live in the settlements and thus the creation of opportunities for further investments (through security of tenure).

Despite the benefits accrued, there are still some challenges that the city/planning authorities or urban land professionals are facing. Although location is crucial to attract land value, the sites on which the informal settlements in Mwanza city are located is quite challenging, particularly in terms of access which creates challenges for the provision of basic services. On the other hand, Ibungilo and Isamilo settlements are located in prime areas with close proximity to the city centre's amenities and services. But due to the land form, land values in the two areas do not match this strategic location in the urban continuum. Also, the investment of inhabitants in building has not attracted a significant rent gap to attract other competing land uses typical in the areas close to the CBDs in Tanzanian cities. Similar to regularisation of favelas in Rio, title deeds in Isamilo, Ibungilo and Magengeni settlements are not associated with a notable increase in land value, since titles have not been issued. But, regularisation has enhanced tenure security in the respective settlements.

Finally, regularisation projects currently being carried out in the country have not addressed the issue of access to land for public use or provision of public services. Indeed, a broader notion of property rights that includes not only the rights of the owner/private sector but also the rights of the community or public is being overlooked (Blanco, 2011). The reality in Dar es Salaam and Mwanza has shown that in most cases private rights to land are largely secured and safeguarded at the expense of public rights to land. This undermines the fundamentals of urban land use planning and the role of the state as the prime custodian/promoter of public interests. Although the government has instituted regularisation guidelines which, among other things, advocate for public or communal areas such as education and healthcare facilities, open spaces and road network systems; effective implementation and follow-up have not been practiced. It is, therefore, important to undertake serious monitoring and evaluation procedures in order to strike a balance between public and private rights on land. 


\section{References}

Blanco, A.G. (2011). Discourses of land alienation and natural property rights: Land entrepreneurialism and informal settlements in Bogotá, Colombia. Planning Theory, 11, pp.20-43. Doi: $10.1177 / 1473095211403124$.

Bourbeau, H. (2001). Property wrongs: How weak ideas gain strong appeal in the world of development economics. Foreign Policy, pp.78-79.

Brown-Luthango, M., Reyes, E. \& Gubevu, M. (2016). Informal settlement upgrading and safety: experiences from Cape Town, South Africa. Journal of Housing and the Built Environment, 32(3), pp.1-23.

Dar es Salaam City Council (DCC). (2004). Dar es Salaam City Profile. Government Printer, Dar es Salaam.

Dar es Salaam City Council (DCC). (2008). Action Plan for upgrading unplanned and unserviced settlements in Dar es Salaam. Dar es Salaam City Council, Dar es Salaam.

de Soto, H. (2000). The mystery of capital: Why capitalism triumphs in the west and fails everywhere else. New York: Basic Books.

Duminy, J. (2011). Literature Survey: Informality and Planning. African Centre for Cities, University of Cape Town, South Africa.

Durand-Lasserve, A. \& Selod, H. (2007). The Formalisation of Urban Land Tenure in Developing Countries. Paper presented at the World Bank's 2007 Urban Research Symposium, May 14-16, Washington DC.

Durand-Lasserve, A. \& Ndiaye, S. (2008). The Social and Economic Impact of Land Titling Programmes in Dakar. Nairobi: UN-HABITAT.

Fernandes, E. (2002). Regularising informal settlements in Brazil: legalisation, security of tenure and city management. Paper presented at the ESF/N-Aerus Annual Workshop 23-26 May, Brussels.

Fernandes, E. (2011). Regularisation of Informal Settlements in Latin America. Cambridge: Lincoln Institute of Land Policy.

Global Publishers. (2019). The Government Reduces Land Costs. Global Publishers. [Online]. Available at:

https://globalpublishers.co.tz/serikali-yashusha-gharama-zaurasimishaji-ardhi/.

Guevara, N.K.A. (2014). Informality and Formalization of Informal Settlements at the Turn of the Third Millennium: Practices and Challenges in Urban Planning. Journal of Studies in Social Sciences, 9(2), pp.247-299.

Hurni, H. (1997). Concepts of sustainable land management. ITC Journal, 3(4), pp.210-215.

Jones, P. (2017). Formalizing the Informal: Understanding the Position of Informal Settlements and Slums in Sustainable Urbanization Policies and Strategies in Bandung, Indonesia. Sustainability, 9, pp.1-27. Doi: $10.3390 /$ su9081436

Kagawa, A. \& Turkstra, J. (2002). The process of urban land tenure formalization in Peru. In: Payne, G. (ed), Land, rights and innovations: Improving tenure security for the urban poor. London: ITDG Publishing. 
Kironde, J.M.L. (2019). Community-Based Settlements Regularisation: Lessons for Scaling up from Makongo Juu Informal Settlement, Dar es Salaam, Tanzania. Current Urban Studies, 7, pp.170-192

Kusiluka, M.M. \& Chiwambo, D. M. (2018). Assessing land titles application and uptake in regularised informal settlements in Tanzania, International Journal of Urban Sustainable Development, 10(3), pp.279-291. DOI: 10.1080/19463138.2018.1536661

Kyessi, A.G. (1997). Shelter Development in Tanzania: Urban Development Policy Considerations. Paper Presented at a National Workshop on Urban Development Policy for Tanzania, Held at Dar es Salaam, Tanzania, 12-14 May 1997.

Kyessi, A.G. (2002). Community participation in urban infrastructure provision: Servicing informal settlements in Dar es Salaam, Tanzania. PhD Thesis. SPRING, Dortmund. University of Dortmund

Kyessi, A.G. (2007). Participatory Planning in Regularisation of Informal Settlements in Mwanza, Tanzania. In: Stojkov, B. and Cavrić, B. (Eds) Territorium. Institute for Spatial Planning at the Faculty of Geography, University of Belgrade

Kyessi, A. \& Sakijege, T. (2014). Formalizing Property Rights in Informal Settlements and its Implications on Poverty Reduction: The Case of Dar es Salaam, Tanzania. Journal of Business and Economics, Academic Star Publishing Company, 5(12), pp. 2353-2371.

Magigi, W. \& Majani, B.B.K. (2006). Housing Themselves in Informal Settlements: A Challenge to Community Growth Processes, Land Vulnerability and Poverty Reduction in Tanzania. 5th FIG Regional Conference Accra, Ghana, March 8-11, 2006.

Magigi, W. (2013). Community Involvement in Informal Settlements Upgrading: Evidence from Dar Es Salaam Metropolitan City, Tanzania. Research on Humanities and Social Sciences, 3(12), pp.7589.

Midheme, E.P.O. (2007). State- vs. community-led land tenure regularisation in Tanzania. The case of Dar es Salaam City. Unpublished MSc. Thesis Eschede: International Institute for Geo-Information Science and Earth Observation. Twente, The Netherlands

Minister for Lands. (2016). Keynote Address. In proceedings of Tanzania Land Surveying Conference. 2nd \& 3rd November, 2016. Dar es Salaam.

Payne, G., Durand-Lasserve, A. \& Rakodi, C. (2009). The limits of land titling and home ownership. Environment and Urbanization, 21(2), pp.443-462.

Perlman, J. E. (2016). The formalization of informal real estate transactions in Rio's favelas. In E. L. Birch, S. Chattaraj, \& S. M. Wachter (Eds.), Slums: How informal real estate markets work. Philadelphia, PA: University of Pennsylvania Press. pp.58-82.

Sliuzas, R. (2004). Managing Urban Informal Settlements: A Study Using Geo-Information in Dar es Salaam, Tanzania. PhD Thesis, University of Utrecht, The Netherlands

Varley, A. (2016). Property titles and the urban poor: from informality to displacement? Planning Theory \& Practice, 18(3), pp.385-404. 
WAT-Human Settlements Trust. (2010). Documentation of Regularisation Experience in Informal Settlements in Kinondoni Municipality in Dar es Salaam. Experience from Hanna Nassif. WAT-Human Settlements Trust, Dar es Salaam.

World Bank (2002). IPEA Urban Research Symposium: Land Development, Urban Policy and Poverty Reduction, Brasilia, Brazil, April 4-6.

World Bank (2000). Cities in Transition. Washington, DC: The World Bank.

UN DESA (2018). The 2018 Revision of the World Urbanization Prospects, the Population Division of the United Nations Department of Economic and Social Affairs.

United Nations (2014). World Urbanization Prospects. New York: United Nations.

United Nations (2016). The World Cities in 2016. New York: United Nations.

UN-Habitat (2010). Citywide Action Plan for Upgrading Unplanned and Unserviced Settlements in Dar es Salaam. Nairobi: UN-HABITAT.

UN-Habitat (2012). Global campaign for secure tenure: A tool for advocating the provision of adequate shelter for the urban poor. Nairobi: UNHABITAT.

UN-Habitat (2016). Fit-For-Purpose Land Administration Guiding Principles for Country Implementation. Nairobi: UN-HABITAT.

United Republic of Tanzania (URT). (1995) National Land Policy. Government Printer, Dar es Salaam.

United Republic of Tanzania (URT). (1999). The National Land Act No.4. Dar es Salaam, Government Printer

United Republic of Tanzania (URT). (2000). National Human Settlements Development Policy. Government Printer, Dar es Salaam.

United Republic of Tanzania (URT). (2013). Dar es Salaam Master Plan Draft Report. Dar es Salaam

Zakayo, E., Mhache, E.P. \& Wakuru, M. (2018). Land Regularization and Community Development Nexus in Cities of Sub-Saharan Africa: A Critical Review with Urban Growth and Development Perspectives. International Journal of Scientific Research and Management. 6(2), pp.1-12. DOI: $10.18535 / \mathrm{ijsrm} / \mathrm{v} 6 \mathrm{i} 2 . \mathrm{g} 01$

\section{Acknowledgement}

The UK Department for International Development (DFID) through the Research for Evidence Division (RED) which funded the Urban Land Nexus and Inclusive Urbanisation Project. 